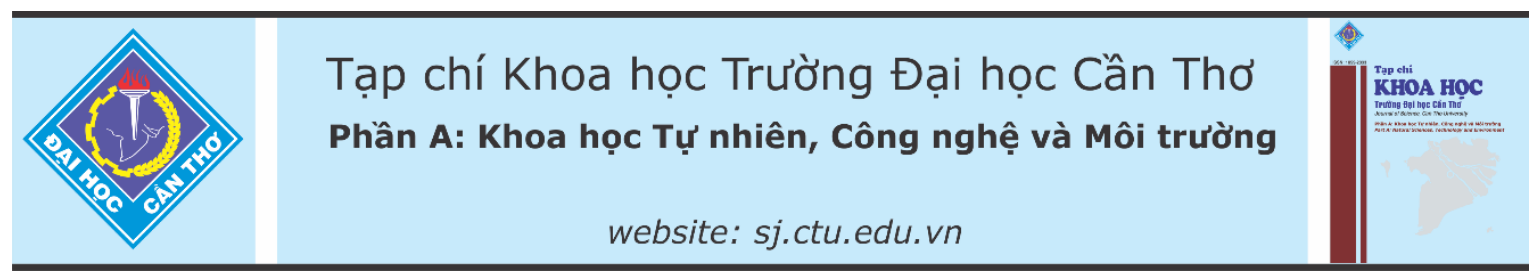

DOI:10.22144/ctu.jvn.2021.003

\title{
ẢNH HƯỞNG CỦA MộT SỐ YẾU TỐ MÔI TRƯờnG LÊN KHẢ NĂNG PHÂN HỦY PHENOL CỦA BẢ DÒNG NÂM MEN
}

\author{
Trần Hoàng Ty ${ }^{1}$, Đỗ Thành Luân ${ }^{2}$, Nguyễn Hửu Thiện ${ }^{2}$ và Nguyễn Khởi Nghĩa ${ }^{2 *}$ \\ ${ }^{1}$ Học viên cao hoc ngành Sinh thái học khóa 25, Khoa Khoa học Tự nhiên, Truờng Đại học Cần Tho \\ ${ }^{2}$ Bộ môn Khoa học đất, Khoa Nông nghiệp, Truờng Đại học Cần Tho \\ *Nguiòi chịu trách nhiệm về bài viết: Nguyễn Khởi Nghĩa (email: nknghia@ctu.edu.vn)
}

\section{Thông tin chung:}

Ngày nhận bài: 15/08/2020

Ngày nhận bài sủa: 01/10/2020

Ngày duyệt đăng: 27/03/2021

\section{Title:}

Effect of some environmental factors on phenol degradation capability of three yeast strains

\section{Tù khóa:}

$\mathrm{NaCl}$, nấm men, phân hủy sinh hoc, phenol, yếu tố môi trường

\section{Keywords:}

Biodegradation, environmental factors, $\mathrm{NaCl}$, phenol, yeast

\begin{abstract}
Phenol, an aromatic organic compound with the molecular formula of $\mathrm{C}_{6} \mathrm{H}_{5} \mathrm{OH}$, toxic to humans and all living things, is commonly found in waste water and sewage sludge. The study aimed at investigating the effect of some selected environmental factors on phenol degradation capability of three yeast strains isolated from the sediment samples of a pond collecting the wastewater from laboratories of College of Agriculture, Can Tho University. The investigation of the environmental factors including $\mathrm{pH}$, temperature, salt concentration, protein source, and carbon source on degradation of phenol was carried out in the minimum salt medium containing $500 \mathrm{mg} . \mathrm{L}^{-1}$ phenol. The concentration of phenol in liquid medium was determined by colorimetric method with Folin - Clocalteu's reagent at $758 \mathrm{~nm}$. The results of the study showed that all three yeast isolates showed their high ability in phenol degradation under the following conditions including $p H$ of the medium from 5 to $7,30^{\circ} \mathrm{C}$, and $\left(\mathrm{NH}_{4}\right)_{2} \mathrm{SO}_{4}$ as nitrogen source for growing. They showed their high salinity tolerance up to to $1.5 \% \mathrm{NaCl}$. In short, the results indicated that these three yeast isolates have a high capacity in application to remediate phenol polluted soils and sediments.
\end{abstract}

\section{TÓM TẮT}

Phenol là một hợp chất hũu co thơm có công thức phân tư $\mathrm{C}_{6} \mathrm{H}_{5} \mathrm{OH}$, có tính độc hại cho con ngườ và động vật, thường được tìm thấy trong nước thải và bùn cống rãnh. Mục tiêu của nghiên cứu nhằm khảo sát ảnh hưởng của một số yếu tố môi trường lên khả năng phân hủy phenol của ba dòng nấm men phân lập tù̀ mẫu đất bùn đáy ao ở khu xả nước thải tù phòng thi nghiệm thuộc Khoa Nông nghiệp, Truờng Đại học Cần Tho: Việc khảo sát các yếu tố môi truờng gồm pH, nhiệt độ, nồng độ muối, nguồn đạm và nguồn carbon được thực hiện trong môi trương khoáng tối thiểu lỏng bổ sung $500 \mathrm{mg} \cdot \mathrm{L}^{-1}$ phenol. Nồng độ phenol trong môi truờng nuôi cấy lỏng được xác định bằng phương pháp so màu với thuốc thủ Folin-Clocalteu's ở bước sóng $758 \mathrm{~nm}$. Kết quả nghiên cưu cho thấy cả ba dòng nấm men phân lập có khả năng phân hủy rất tổt phenol ở điều kiện môi trương $p H$ tù 5 đến 7 , khả năng chịu mặn lên đến $1,5 \% \mathrm{NaCl}$, nhiệt độ $30^{\circ} \mathrm{C}$ và nguồn đạm $\left(\mathrm{NH}_{4}\right)_{2} \mathrm{SO}_{4}$. Tóm lại, kết quả cho thấy ba dòng nấm men thử nghiệm có tiềm năng ứng dụng cao trong việc xủ lý đất và trầm tích ô nhiếm với phenol. 


\section{GIỚI THIỆ}

Trong những năm gần đây, sự ô nhiễm các độc chất môi trường do hoạt động công nghiệp và nông nghiệp đang là một trong những vấn đề nghiêm trọng toàn cầu. Từ nguồn nước thải, các độc chất này đi vào môi trường và tác động xấu đến sinh vật sống. Một số hydrocarbon thơm đa vòng (polycyclic aromatic hydrocarbons) được tạo ra trong quá trình tinh lọc dầu khoáng, sơn mài, các hàng dệt may, vật liệu tái chế,... có khả năng ảnh hưởng lớn đến sức khỏe con người như gây ngộ độc, đột biến và ung thư (World Health Organization, 1998). Trong đó, phenol là một hợp chất được sử dụng khá phổ biến trong tổng hợp nhựa và diệt khuẩn thuộc nhóm các độc chất nguy hiểm và có độ độc cao. Do đặc tính tan hoàn toàn trong nước, khó phân hủy và gây mùi khó chịu, hợp chất này ảnh hưởng lớn đến đời sống và hoạt động sản xuất. Nồng độ gây chết của phenol đối với động vật biển dao động từ $5-25 \mathrm{mg} \cdot \mathrm{L}^{-1}$ (Abarian et al., 2015). Ngoài ra, phenol là một hợp chất vòng thơm rất độc, khó phân hủy, gây ra mùi khó chịu, ảnh hưởng lớn đến sản xuất nông nghiệp, gia tăng bệnh tật và tỷ lệ người mắc bệnh kể cả ở nồng độ rất thấp, nó cũng là tác nhân tiềm ẩn gây ung thư và nhiều bệnh nguy hiểm cho con người (Bruce et al., 1987).

Có nhiều phương pháp dùng để xử lý ô nhiễm đất, nước và trầm tích với phenol như sử việc sử dụng hóa chất, hấp phụ và lắng đọng. Tuy nhiên, các phương pháp này đòi hỏi chi phí lớn và có thể gây ô nhiễm thứ cấp. Hiện nay, việc xử lý các hợp chất hữu cơ có độ độc cao theo phương pháp sinh học đang là một hướng đi mới đầy triển vọng và thu hút được nhiều sự quan tâm trong nghiên cứu trên thế giới. Theo đó, quá trình phân hủy các độc chất hữu cơ bằng biện pháp sinh học có thể ứng dụng rộng rãi trong điều kiện tự nhiên, có độ an toàn cao, thân thiện với môi trường và chi phí thấp. Có nhiều nghiên cứu về phân lập và tuyển chọn các dòng vi sinh vật gồm nấm, vi khuẩn, xạ khuẩn, nấm men,... phân hủy tốt phenol đã được thực hiện và công bố. Năm 2006, Krallish et al. đã công bố các chủng nấm men có khả năng tạo biofilm như Candida tropicalis, Cryptococcus terreus, Rhodotorula creatinivora và Rhodosporidium toruloides có nhiều tiềm năng ứng dụng trong xử lý nước thải ô nhiễm với phenol một cách hiệu quả và an toàn. Năm 2017, Filipowicz et al. đã phân lập được ba dòng nấm men Candida subhashii $\mathrm{A} 01_{1}$, Candida oregonensis $\mathrm{B} 02_{1}$ và Schizoblastosporion starkeyihenricii $\mathrm{L} 01_{2}$ từ đất và nước thải ở nhà máy than bùn Rucianca. Kết quả nghiên cứu cho thấy cả ba dòng nấm men phân lập trên có khả năng phân hủy hoàn toàn lượng phenol sau 2 ngày bố trí thí nghiệm với nồng độ ban đầu dao động từ 500 đến $1000 \mathrm{mg} \cdot \mathrm{L}^{-1}$. Tuy nhiên, các nghiên cứu về các điều kiện về môi trường sống như $\mathrm{pH}$, nhiệt độ, ánh sáng và dinh dưỡng phù hợp cho các dòng nấm men phân lập đề tăng khả năng phân hủy phenol trong môi trường nuôi cấy lỏng còn rất hạn chế. Vì vậy, nghiên cứu này được thực hiện nhằm mục tiêu khảo sát các yếu tố môi trường như $\mathrm{pH}$, nhiệt độ, nồng độ muối, nguồn đạm và nguồn carbon lên khả năng phân hủy phenol của 3 dòng nấm men phân lập.

\section{PHƯƠNG PHÁP NGHIÊN CÚU}

\subsection{Nguồn nấm men}

Ba dòng nấm men ký hiệu PS6, PS1.1 và PS1T phân hủy tốt phenol được phân lập từ mẫu bùn đáy ao ở khu xả thải phòng thí nghiệm thuộc Khoa Nông nghiệp, Trường Đại học Cần Thơ. Khả năng phân hủy phenol của 3 dòng nấm men sau 3 ngày bố trí thí nghiệm là $100 \%$ với nồng độ phenol ban đầu là $500 \mathrm{mg} . \mathrm{L}^{-1}$.

2.2. Khảo sát ảnh hưởng của các mức $\mathbf{p H}$ môi trường nuôi cấy khác nhau lên khả năng phân hủy phenol của ba dòng nấm men kí hiệu PS1T, PS6 và PS1.1

\subsubsection{Chuẩn bị nguồn nấm men}

Sinh khối của các dòng nấm men phân lập được nuôi tăng sinh trong $50 \mathrm{~mL}$ môi trường TSB tiệt trùng và lắc tới tốc độ 110 vòng/phút trong 3 ngày trong tối dưới điều kiện nhiệt độ phòng thí nghiệm. Thành phần của môi trường TSB gồm $30 \mathrm{~g}$ Tryptone Soya Broth hòa tan trong $1 \mathrm{~L}$ nước khử khoáng. Sau thời gian nuôi cấy, tiến hành thu sinh khối nấm men bằng cách ly tâm dịch huyền phù nấm men đã được tăng sinh với tốc độ 7.000 vòng/phút trong 5 phút, loại bỏ phần dịch trong, thu phần sinh khối nấm men nằm bên dưới. Hiệu chỉnh mật số nấm men về $\mathrm{OD}_{600}$ $=0,7$ với nước cất tiệt trùng. Khi đó mật số nấm men tương đương $10^{7} \mathrm{CFU} \cdot \mathrm{mL}^{-1}$.

Đối với các thí nghiệm tiếp theo về khảo sát ảnh hưởng của nhiệt độ, nồng độ $\mathrm{NaCl}$, nguồn đạm và nguồn carbon lên khả năng phân hủy phenol, việc chuẩn bị nguồn nấm men cho từng thí nghiệm được thực hiện tương tự.

\subsubsection{Bố trí thí nghiệm}

Thí nghiệm được thực hiện trong bình tam giác $100 \mathrm{~mL}$ gồm 4 nghiệm thức với 3 lần lặp lại cho mỗi nghiệm thức tương ứng với 3 bình tam giác. Bốn nghiệm thức tương ứng với 4 mức $\mathrm{pH}$ khác nhau gồm $3,5,7$ và 9 cho mỗi dòng nấm men và mỗi mức 
pH khác nhau có nghiệm thức đối chứng đi kèm (không bổ sung nấm men). Cách thực hiện như sau: Hút $1 \mathrm{~mL}$ dịch nấm men đã được hiệu chỉnh về $\mathrm{OD}_{600}=0,7$ vào bình tam giác $100 \mathrm{~mL}$ chứa $49 \mathrm{~mL}$ môi trường khoáng tồi thiểu bổ sung $500 \mathrm{mg} . \mathrm{L}^{-1}$ phenol. Thành phần của $1 \mathrm{~L}$ môi trường khoáng tối thiểu lỏng gồm $\left(\mathrm{g} \cdot \mathrm{L}^{-1}\right): 0,01 \mathrm{~g} \mathrm{MnSO}{ }_{4} \cdot \mathrm{H}_{2} \mathrm{O} ; 0,1 \mathrm{~g}$ $\mathrm{MgSO}_{4} ; 0,1 \mathrm{~g} \mathrm{NaCl} ; 0,2 \mathrm{~g} \mathrm{KH}_{2} \mathrm{PO}_{4} ; 0,4 \mathrm{~g} \mathrm{~K}_{2} \mathrm{HPO}_{4}$; $0,4 \mathrm{~g}\left(\mathrm{NH}_{4}\right)_{2} \mathrm{SO}_{4}$ và $0,01 \mathrm{~g} \mathrm{Na}_{2} \mathrm{MoO}_{4} \cdot 2 \mathrm{H}_{2} \mathrm{O}$. Hiệu chỉnh $\mathrm{pH}$ môi trường về các mức khác nhau gồm 3 , 5,7 và 9 tương ứng với các nghiệm thức thí nghiệm trước khi tiệt trùng ướt ở $121^{\circ} \mathrm{C}$ trong 20 phút với áp suất $1 \mathrm{~atm}$. Các bình tam giác chứa mẫu được lắc trên máy lắc tròn với tốc độ 110 vòng.phút ${ }^{-1}$ trong tối ở nhiệt độ phòng thí nghiệm. Nồng độ phenol trong môi trường nuôi cấy lỏng được xác định vào các thời điểm $0,1,2,3$ và 5 ngày sau khi nuôi cấy bằng phương pháp so màu với thuốc thử Folin Ciocalteu's (Imelda and Chandrika., 1999). Cách thực hiện như sau: Trước tiên, hút $1 \mathrm{~mL}$ dung dịch mẫu môi trường nuôi cấy tại thời điểm thu mẫu, $\mathrm{ly}$ tâm ở tốc độ 12.000 vòng.phút ${ }^{-1}$ trong 5 phút để loại bỏ sinh khối VSV, dung dịch mẫu (phần nước nằm bên trên) sau ly tâm được pha loãng với nước khử khoáng theo tỷ lệ phù hợp. Sau đó, hút $3 \mathrm{~mL}$ mẫu cho vào ống nghiệm $10 \mathrm{~mL}$, thêm $250 \mu \mathrm{L}$ Folin Ciocalteu trộn đều và để yên trong 5 phút, tiếp tục thêm $750 \mu \mathrm{L} \mathrm{Na}_{2} \mathrm{CO}_{3}(20 \%)$ và trộn đều. Tiến hành cho thêm $1 \mathrm{~mL}$ nước khử khoáng và trộn đều, sau đó để yên trong 2 giờ và trong tối. Cuối cùng tiến hành đo độ hấp thu ở bước sóng $758 \mathrm{~nm}$ trên máy quang phổ Muntiskan spectrum (Thermo - Mỹ).

Tương tự, nồng độ phenol còn lại trong môi trường nuôi cấy lỏng ở các thí nghiệm khảo sát ảnh hưởng của các yếu tố gồm nhiệt độ, nồng độ $\mathrm{NaCl}$, nguồn đạm và nguồn carbon được xác định bằng phương pháp so màu với thuốc thử Folin Ciocalteu's giống như nội dung này.

\subsection{Khảo sát ảnh hưởng của nhiệt độ lên khả} năng phân hủy phenol của ba dòng nấm men kí hiệu PS1T, PS6 và PS1.1

Thí nghiệm được thực hiện trong bình tam giác $100 \mathrm{~mL}$ gồm 2 nghiệm thức với 3 lần lặp lại cho mỗi nghiệm thức tương ứng với 3 bình tam giác. Hai nghiệm thức tương ứng với 2 mức nhiệt độ thí nghiệm khác nhau gồm (1) nhiệt độ phòng thí nghiệm $\left(30^{\circ} \mathrm{C}\right)$ và $(2) 40^{\circ} \mathrm{C}$ cho mỗi dòng nấm men thí nghiệm và mỗi mức nhiệt độ khác nhau có nghiệm thức đối chứng đi kèm (không bổ sung nấm men). Cách thực hiện như sau: hút $1 \mathrm{~mL}$ dịch nấm men đã được hiệu chỉnh về $\mathrm{OD}_{600}=0,7$ vào bình tam giác $100 \mathrm{~mL}$ chứa $49 \mathrm{~mL}$ môi trường khoáng tối thiểu bổ sung $500 \mathrm{mg} . \mathrm{L}^{-1}$ phenol. Môi trường nuôi cấy khoảng tối thiểu lỏng bổ sung phenol được tiệt trùng ướt ở $121^{\circ} \mathrm{C}$ trong 20 phút với áp suất $1 \mathrm{~atm}$. Các bình tam giác chứa mẫu được lắc trên máy lắc tròn với tốc độ 110 vòng.phút ${ }^{-1}$ trong tối ở nhiệt độ phù hợp với từng nghiệm thức về nhiệt độ. Nồng độ phenol trong môi trường nuôi cấy lỏng được xác định vào các thời điểm $0,1,2,3$ và 5 ngày sau khi nuôi cấy.

2.4. Khảo sát ảnh hưởng của nồng độ muối của môi trường nuôi cấy lên khả năng phân hủy phenol của ba dòng nấm men kí hiệu PS1T, PS6 và PS1.1

Thí nghiệm được thực hiện trong bình tam giác $100 \mathrm{~mL}$ gồm 4 nghiệm thức với 3 lần lặp lại cho mỗi nghiệm thức tương ứng với 3 bình tam giác. Bốn nghiệm thức tương ứng với 4 nồng độ muối khác nhau gồm $0 \%, 0,5 \%, 1 \%$ và $1,5 \% \mathrm{NaCl}$ cho mỗi dòng nấm men thí nghiệm và mỗi mức nồng độ muối khác nhau có nghiệm thức đối chứng đi kèm (không bổ sung nấm men). Cách thực hiện như sau: hút $1 \mathrm{~mL}$ dịch nấm men đã được hiệu chỉnh về $\mathrm{OD}_{600}$ $=0,7$ vào bình tam giác $100 \mathrm{~mL}$ chứa $49 \mathrm{~mL}$ môi trường khoáng tồi thiểu bổ sung $500 \mathrm{mg} \cdot \mathrm{L}^{-1}$ phenol. Các môi trường nuôi cấy khoáng tối thiểu lỏng bổ sung phenol chứa các nồng độ muối khác nhau và riêng lẻ được được tiệt trùng ướt ở $121^{\circ} \mathrm{C}$ trong 20 phút với áp suất $1 \mathrm{~atm}$. Các bình tam giác chứa mẫu được lắc trên máy lắc tròn với tốc độ 110 vòng.phút ${ }^{1}$ trong tối ở nhiệt độ phòng thí nhiệm. Nồng độ phenol trong môi trường nuôi cấy lỏng được xác định vào các thời điểm $0,1,2,3$ và 5 ngày sau khi nuôi cấy.

2.5. Khảo sát ảnh hưởng của việc bổ sung các nguồn đạm khác nhau trong môi trường nuôi cấy lên khả năng phân hủy phenol của ba dòng nấm men kí hiệu PS1T, PS6 và PS1.1

Thí nghiệm được thực hiện trong bình tam giác $100 \mathrm{~mL}$ gồm 3 nghiệm thức với 3 lần lặp lại cho mỗi nghiệm thức tương ứng với 3 bình tam giác. $\mathrm{Ba}$ nghiệm thức tương ứng với 3 nguồn đạm khác nhau được bổ sung vào môi trường nuôi cấy gồm: (1) $\left(\mathrm{NH}_{4}\right)_{2} \mathrm{SO}_{4}$, (2) $\mathrm{KNO}_{3}$ và (3) Casein (trọng lượng của 3 nguồn đạm là 0,4 g.. $\left.\mathrm{L}^{-1}\right)$ cho mỗi dòng nấm men thí nghiệm và mỗi nguồn đạm khác nhau có nghiệm thức đối chứng đi kèm (không bổ sung nấm men). Cách thực hiện như sau: hút $1 \mathrm{~mL}$ dịch nấm men đã được hiệu chỉnh về $\mathrm{OD}_{600}=0,7$ vào bình tam giác $100 \mathrm{~mL}$ chứa $49 \mathrm{~mL}$ môi trường khoáng tối thiểu bổ sung $500 \mathrm{mg} \cdot \mathrm{L}^{-1}$ phenol. Các môi trường nuôi cấy khoáng tối thiểu lỏng bổ sung phenol chứa các nguồn đạm khác nhau và riêng lẻ được được tiệt 
trùng ướt ở $121^{\circ} \mathrm{C}$ trong 20 phút với áp suất $1 \mathrm{~atm}$. Các bình tam giác chứa mẫu được lắc trên máy lắc tròn với tốc độ 110 vòng.phút ${ }^{-1}$ trong tối ở nhiệt độ phòng thí nhiệm. Nồng độ phenol trong môi trường nuôi cấy lỏng được xác định vào các thời điểm 0,1 , 2,3 và 5 ngày sau khi nuôi cấy.

2.6. Khảo sát ảnh hưởng của việc bổ sung các nguồn carbon khác nhau trong môi trường nuôi cấy lên khả năng phân hủy phenol của ba dòng nấm men kí hiệu PS1T, PS6 và PS1.1

Thí nghiệm được thực hiện trong bình tam giác $100 \mathrm{~mL}$ gồm 3 nghiệm thức với 3 lần lặp lại cho mỗi nghiệm thức tương ứng với 3 bình tam giác. $\mathrm{Ba}$ nghiệm thức tương ứng với 3 nguồn carbon khác nhau được bổ sung vào môi trường nuôi cấy gồm: (1) $1 \%$ glucose, (2) $1 \%$ sucrose và (3) $1 \%$ manitol cho mỗi dòng nấm men thí nghiệm và mỗi nguồn carbon khác nhau có nghiệm thức đối chứng âm (không bổ sung nấm men, không bổ sung nguồn carbon khác) và nghiệm thức đối chứng dương (môi trường khoáng bố sung $500 \mathrm{mg} \cdot \mathrm{L}^{-1}$ phenol như nguồn carbon duy nhất) đi kèm. Cách thực hiện như sau: hút $1 \mathrm{~mL}$ dịch nấm men đã được hiệu chỉnh về $\mathrm{OD}_{600}=0,7$ vào bình tam giác $100 \mathrm{~mL}$ chứa $49 \mathrm{~mL}$ môi trường khoáng tồi thiểu bổ sung $500 \mathrm{mg} \cdot \mathrm{L}^{-1}$ phenol. Các môi trường nuôi cấy khoáng tối thiểu lỏng bổ sung phenol chứa các nguồn carbon khác nhau và riêng lẻ được được tiệt trùng ướt ở $121^{\circ} \mathrm{C}$ trong 20 phút với áp suất $1 \mathrm{~atm}$. Các bình tam giác chứa mẫu được lắc trên máy lắc tròn với tốc độ 110 vòng.phút ${ }^{-1}$ trong tối ở nhiệt độ phòng thí nhiệm. Nồng độ phenol trong môi trường nuôi cấy lỏng được xác định vào các thời điểm $0,1,2,3$ và 5 ngày sau khi nuôi cấy.

\subsection{Phương pháp xử lý số liệu}

Số liệu thí nghiệm được xử lý trên bảng tính Excel và phân tích thống kê bằng phần mềm Minitab version 16.2. Ngoài ra, các nghiệm thức đối chứng được trình bày trong các Hình trong phần kết quả và thảo luận là giá trị trung bình của tất cả các lặp lại của các nghiệm thức đối chứng (không chủng nấm men) do nồng độ phenol còn lại trong môi trường nuôi cấy lỏng của các nghiệm thức đối chứng không chủng nấm men ở các mức $\mathrm{pH}$, nhiệt độ, nồng độ muối, nguồn đạm và carbon khác nhau biến động không đáng kể khi so sánh với nhau.

\section{KÊTT QUẢ VÀ THẢO LUẬN}

3.1. Ảnh hưởng của các mức $\mathrm{pH}$ môi trường nuôi cấy khác nhau lên khả năng phân hủy phenol của ba dòng nấm men kí hiệu PS1T, PS6 và PS1.1

Kết quả thí nghiệm khảo sát ảnh hưởng của các mức $\mathrm{pH}$ môi trường nuôi cấy lên khả năng phân hủy phenol của ba dòng nấm men kí hiệu PS1T, PS6 và PS1.1 (Hình 1) cho thấy nồng độ phenol giảm dần theo thời gian thí nghiệm và các nghiệm thức thí nghiệm khi bố trí với cùng một dòng nấm men đều khác biệt ý nghĩa thống kê khi so sánh với nhau $(\mathrm{p}<0,05)$ ở tất cả các thời điểm lấy chỉ tiêu. Kết quả thí nghiệm cũng cho thấy khả năng phân hủy phenol trong môi trường nuôi cấy lỏng của 3 dòng nấm men sau 3 ngày bố trí thí nghiệm là rất cao với hiệu suất phân hủy cao hơn $99 \%$.

Thêm vào đó, kết quả khảo sát còn cho thấy cả 3 dòng nấm men thử nghiệm có ký hiệu PS1T, PS6 và PS1.1 đều thể hiện khả năng phân hủy phenol tốt nhất ở môi trường nuôi cấy lỏng có $\mathrm{pH} 5$. Sau 1 ngày nuôi cấy, nồng độ phenol còn lại trong môi trường nuôi cấy lỏng của 3 dòng nấm men này lần lượt đạt 71,54 và $74 \mathrm{mg} . \mathrm{L}^{-1}$ tương ứng với $85,4,88,9$ và $88,7 \%$ hiệu suất phân hủy. Tiếp tục sau 2 ngày thí nghiệm, nồng đồ phenol còn lại trong môi trưởng nuôi cấy lỏng của 3 dòng nấm men này là $0 \mathrm{mg} \cdot \mathrm{L}^{-1}$, thể hiện hiệu suất phân hủy đạt $100 \%$ ở nghiệm thức môi trường nuôi cấy $\mathrm{pH} 5$. Vào thời điểm 3 ngày thí nghiệm, tất cả các nghiệm thức chủng với 3 dòng nấm men này ở các mức $\mathrm{pH}$ khác nhau có nồng độ phenol còn lại trong môi trường nuôi cấy lỏng là 0 mg.L $L^{-1}$ và đạt hiệu suất phân hủy $100 \%$, ngoại trừ nghiệm thức chủng dòng nấm men ký hiệu PS1T ở mức $\mathrm{pH} 3$ có nồng độ phenol còn lại khá cao $(363,6$ mg. $\left.L^{-1}\right)$ sau 3 ngày thí nghiệm và tương ứng hiệu suất phân hủy đạt $16,1 \%$. Kết quả này tương tự với kết quả nghiên cứu của Phạm Hương Sơn và $c t v$. (1999) cho thấy pH môi trường nuôi cấy lỏng thích hợp cho sự phát triển của các dòng nấm men phân lập là 5,5 . 

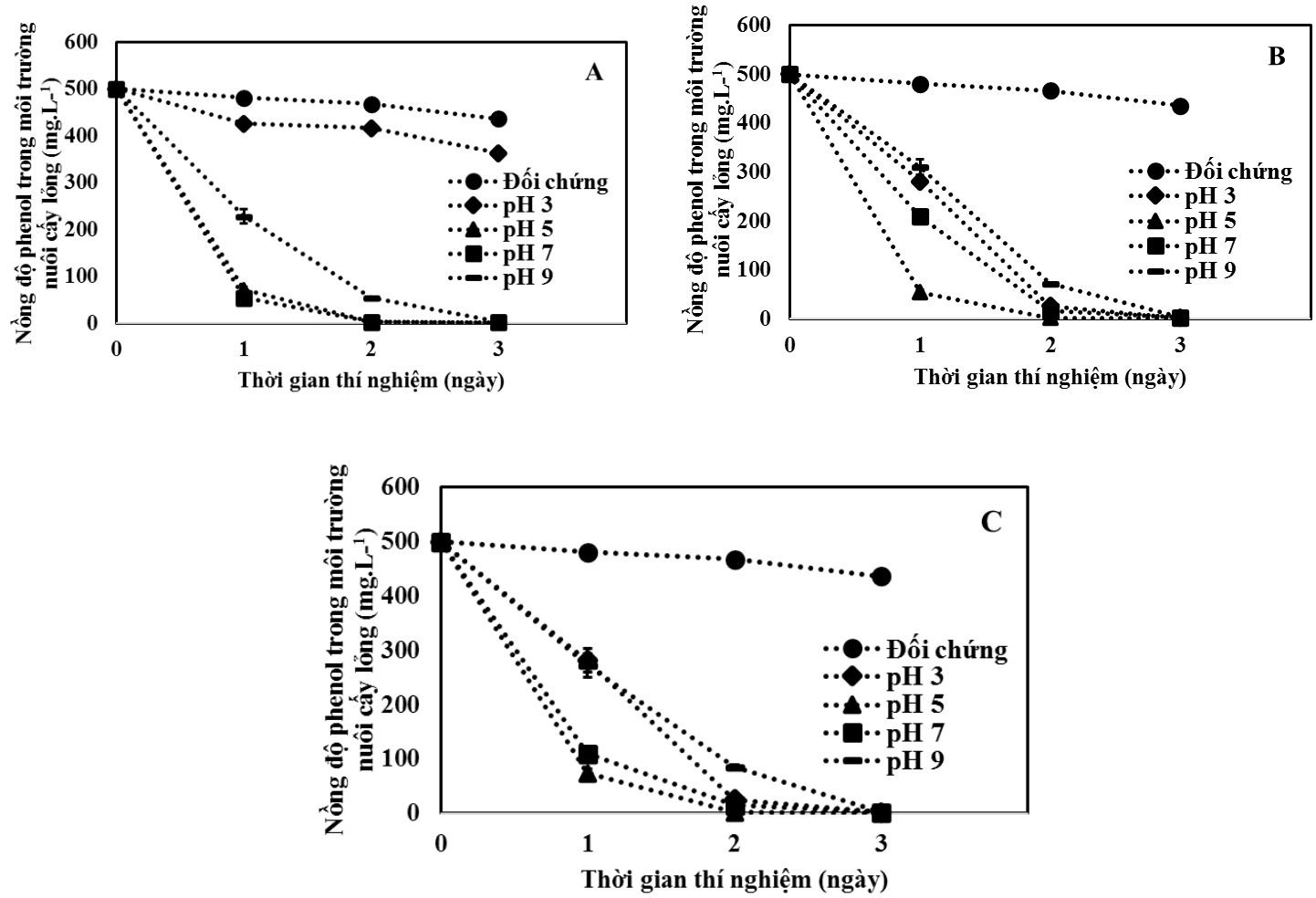

Hình 1. Khả năng phân hủy phenol của ba dòng nấm men phân lập (A: PS1T; B: PS6 và C: PS1.1) ở các mức $\mathrm{pH}$ môi trường nuôi cấy lỏng khác nhau ( $\mathrm{n}=3$ và độ lệch chuẩn)

3.2. Ảnh hưởng của các mức nhiệt độ nuôi cấy khác nhau lên khả năng phân hủy phenol của ba dòng nấm men kí hiệu PS1T, PS6 và PS1.1

Kết quả thí nghiệm khảo sát ảnh hưởng của các mức nhiệt độ nuôi cấy lên khả năng phân hủy phenol của ba dòng nấm men kí hiệu PS1T, PS6 và PS1.1 được trình bày ở Hình 2. Kết quả cho thấy nồng độ phenol giảm dần theo thời gian thí nghiệm và các nghiệm thức thí nghiệm khi bố trí với cùng một dòng nấm men đều có khác biệt ý nghĩa thống kê khi so sánh với nhau $(\mathrm{p}<0,05)$ ở tất cả các thời điểm lấy chỉ tiêu.

Ngoài ra, kết quả khảo sát cho thấy cả 3 dòng nấm men thử nghiệm có ký hiệu PS1T, PS6 và PS1.1 đều thể hiện khả năng phân hủy phenol tốt nhất ở điều kiện nhiệt độ phòng thí nghiệm $\left(30^{\circ} \mathrm{C}\right)$ ở tất cả các thời điểm thu mẫu. Sau 2 ngày nuôi cấy, nồng độ phenol còn lại trong môi trường nuôi cấy lỏng của 3 dòng nấm men này ở điều kiện phòng thí nghiệm $\left(30^{\circ} \mathrm{C}\right)$ lần lượt là 19,29 , và $50 \mathrm{mg} . \mathrm{L}^{-1}$ và tương ứng với hiệu suất phân hủy là 96,94 và $90 \%$. Ngoại trừ dòng nấm men PS1T, hai dòng nấm men còn lại (PS6 và PS1.1) vẫn thể hiện sự phân hủy phenol tốt ở nghiệm thức có nhiệt độ $40^{\circ} \mathrm{C}$ thông qua việc giảm nồng độ phenol trong môi trường nuôi cấy lỏng theo thời gian thí nghiệm. Ngoài ra, dòng nấm men ký hiệu PS1.1 và PS6 phân hủy hoàn toàn nồng độ phenol lần lượt sau 3 và 5 ngày thí nghiệm ở nghiệm thức $40^{\circ} \mathrm{C}$. Như vậy, mức nhiệt độ phòng thí nghiệm $\left(30^{\circ} \mathrm{C}\right)$ là mức nhiệt độ nuôi cấy thích hợp nhất giúp 3 dòng nấm men phân hủy phenol tốt nhất.

Ngoài ra, hai dòng nấm men PS6 và PS1.1 vẫn có khả năng phân hủy phenol hiệu quả ở mức nhiệt độ nuôi cấy $40^{\circ} \mathrm{C}$. 

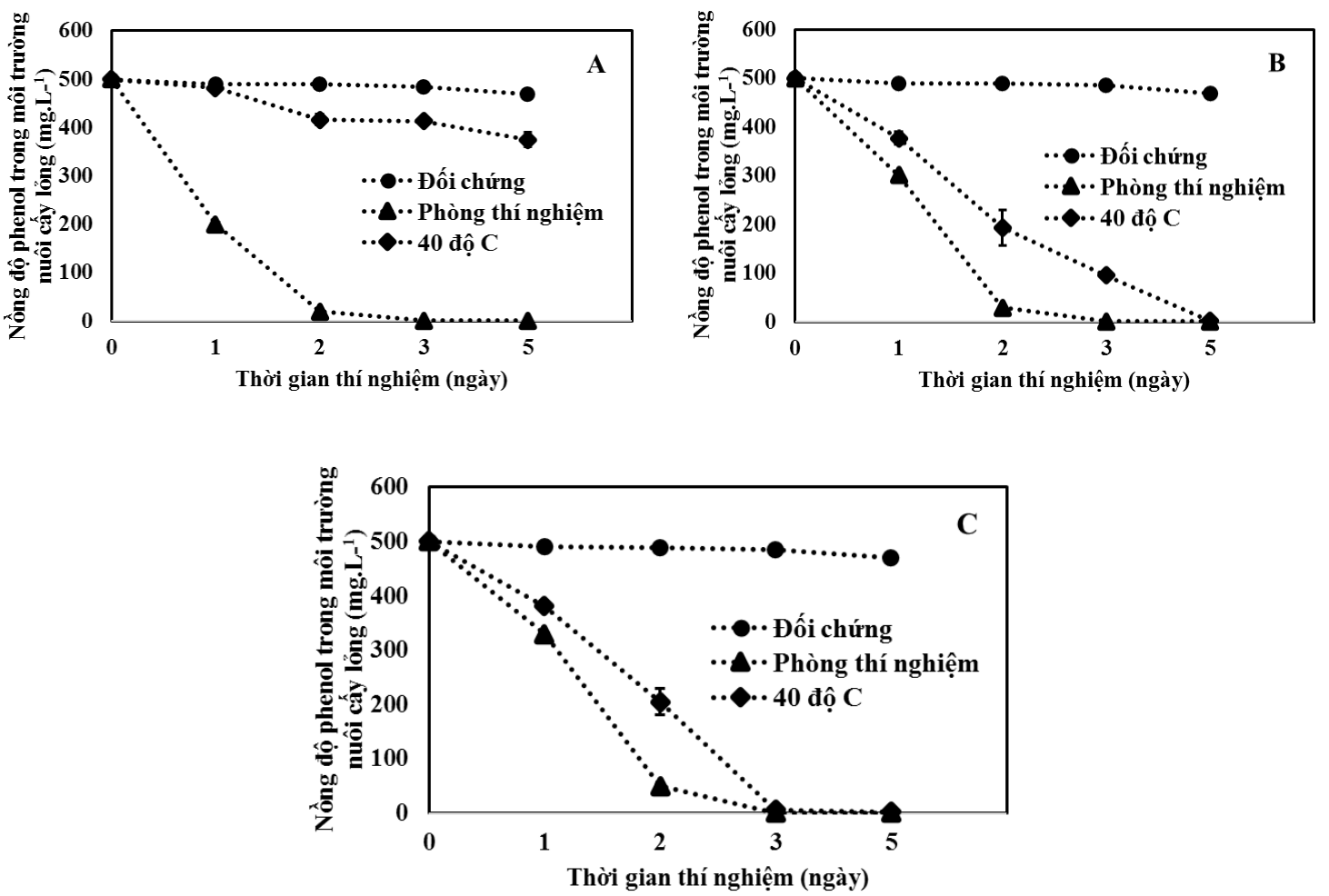

Hình 2. Khả năng phân hủy phenol của ba dòng nấm men phân lập (A: PS1T; B: PS6 và C: PS1.1) ở các điệu kiện nhiệt độ môi trường nuôi cấy lỏng khác nhau ( $\mathrm{n}=3$ và độ lệch chuẩn)

3.3. Ảnh hưởng của việc bổ sung các nồng độ muối NaCl khác nhau trong môi trường nuôi cấy lỏng lên khả năng phân hủy phenol của ba dòng nấm men kí hiệu PS1T, PS6 và PS1.1

Kết quả thí nghiệm khảo sát ảnh hưởng của các nồng độ muối khác nhau trong môi trường nuôi cấy lỏng lên khả năng phân hủy phenol của ba dòng nấm men kí hiệu PS1T, PS6 và PS1.1 được trình bày ở Hình 3. Nồng độ phenol của các nghiệm thức có xu hướng giảm dần theo thời gian thí nghiệm, đặc biệt ở các nghiệm thức có chủng các dòng nấm men và các nghiệm thức thí nghiệm khi bố trí với cùng một dòng nấm men đều khác biệt ý nghĩa thống kê khi so sánh với nhau $(\mathrm{p}<0,05)$ ở tất cả các thời điểm thu mẫu. Kết quả thí nghiệm cũng cho thấy khả năng phân hủy phenol trong môi trường nuôi cấy lỏng của
3 dòng nấm men sau 2 ngày bố trí thí nghiệm là khá cao với hiệu suất phân hủy từ 98,5 đến $99 \%$ (ngoại trừ các nghiệm thức đối chứng không chủng nấm men). Do nồng độ phenol trong các nghiệm thức không chủng nấm men ở các mức nồng độ muối khác nhau không thay đổi hoặc thay đổi rất ít, do đó, các nghiệm thức đối chứng này được xem là như nhau và kết quả trình bày trong Hình 3 của nghiệm thức đối chứng là những giá trị trung bình của 12 lần lặp lại từ 4 nghiệm thức đối chứng không chủng nấm men. Nghiệm thức đối chứng không chủng nấm men có nồng độ phenol còn lại trong môi trường nuôi cấy lỏng cao nhất. Tuy nhiên, khi có chủng các dòng nấm men vào hàm lượng phenol trong tất cả các nghiệm thức thí nghiệm đều giảm xuống rất mạnh theo thời gian thí nghiệm. 

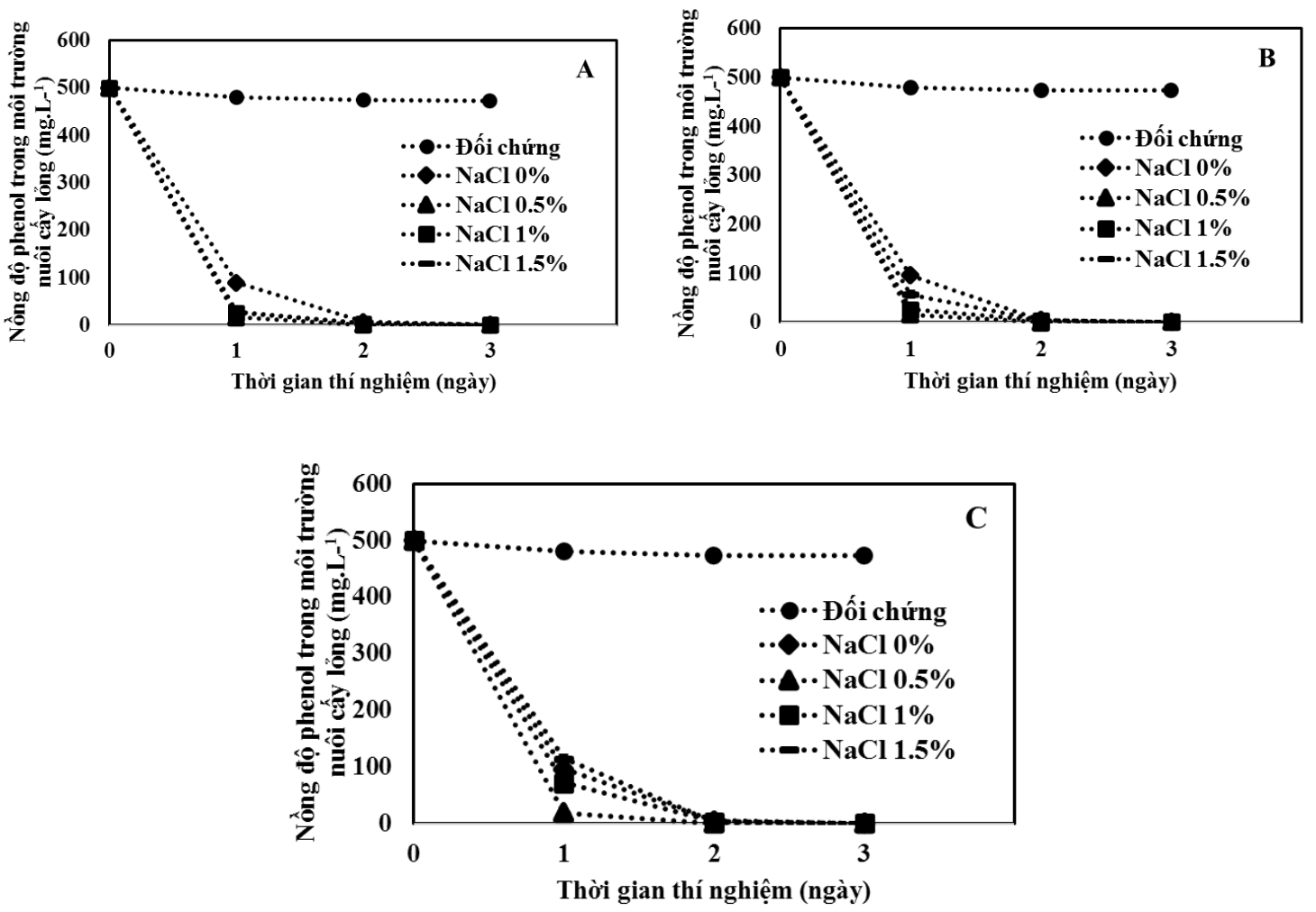

Hình 3. Khả năng phân hủy phenol của ba dòng nấm men phân lập (A: PS1T; B: PS6 và C: PS1.1) ở các nồng độ muối khác nhau trong môi trường nuôi cấy lỏng $(\mathrm{n}=3$ và độ lệch chuẩn)

Ngoài ra, cả 3 dòng nấm men đều thể hiện khả năng phân hủy phenol tốt hơn ở các nghiệm thức có bổ sung nồng độ muối $\mathrm{NaCl}$. Trong khi đó, nghiệm thức không bổ sung muối $\mathrm{NaCl}$ cho khả năng phân hủy phenol chậm hơn. Cụ thể, sau 1 ngày nuôi cấy, 3 dòng nấm men kí hiệu PS1T, PS6 và PS1.1 thể hiện khả năng phân hủy phenol rất cao đối với các nghiệm thức có bổ sung $\mathrm{NaCl}$ từ 0,5 đến $1,5 \%$ với nồng độ phenol còn lại trong môi trường nuôi cấy dao động từ 16 đến $72,4 \mathrm{mg} . \mathrm{L}^{-1}$ (ngoại trừ nghiệm thức bổ sung nồng độ muối $1,5 \%$ chủng dòng nấm men PS1.1 (115,1 mg.L $\left.\left.{ }^{-1}\right)\right)$ trong khi đó nghiệm thức không bổ sung muối $\mathrm{NaCl}(0 \%)$ cho khả năng phân hủy phenol thấp hơn với nồng độ phenol còn lại trong môi trường nuôi cấy lỏng dao động trong khoảng từ 90 đến $97 \mathrm{mg} \cdot \mathrm{L}^{-1}$. Tuy nhiên, vào thời điểm 2 ngày thí nghiệm, tất cả các nghiệm thức có chủng 3 dòng nấm men thể hiện việc phân hủy hầu như hoàn toàn hàm lượng phenol có trong môi trường nuôi cấy lỏng và tương ứng với hiệu suất phân hủy là $100 \%$. Kết quả này cho thấy việc bổ sung các nồng độ muối $\mathrm{NaCl}$ khác nhau dao động từ $0,5-1,5 \% \mathrm{NaCl}$ giúp gia tăng tốc độ phân hủy hoạt chất phenol của 3 dòng nấm men thử nghiệm trong môi trường nuôi cấy lỏng. Kết quả nghiên cứu này phù hợp với nghiên cứu của Lê Thị Nhi Công và ctv. (2013) cho thấy chủng nấm men Trichosporon asahii QN-B1 phân lập từ vùng ô nhiễm dầu ở vùng biển Hạ Long có khả năng phân hủy phenol cao ở môi trường nuôi cấy lỏng có bổ sung $1,5 \% \mathrm{NaCl}$ do có khả năng tạo màng sinh học.

3.4. Ảnh hưởng của các việc bổ sung các nguồn đạm khác nhau trong môi trường nuôi cấy lỏng lên khả năng phân hủy phenol của ba dòng nấm men kí hiệu PS1T, PS6 và PS1.1

Kết quả khảo sát ảnh hưởng của việc bổ sung các nguồn đạm khác nhau vào trong môi trường môi trường nuôi cấy lỏng lên khả năng phân hủy phenol của 3 dòng nấm men thử nghiệm được trình bày trong Hình 4. Nhìn chung, nồng độ phenol còn lại trong môi trường nuôi cấy lỏng giảm xuống nhanh theo thời gian thí nghiệm, ngoại trừ các nghiệm thức đối chứng không chủng nấm men. Ngoài ra, các nghiệm thức có sự khác biệt ý nghĩa thống kê khi so sánh với nhau trong cùng một thời điểm thu mẫu $(\mathrm{p}<0,05)$. Trong đó, nghiệm thức đối chứng không chủng nấm men luôn cho nồng độ phenol còn lại cao nhất ở tất cả các thời điểm thu mẫu. Cả 3 dòng nấm 
men thử nghiệm (PS1T, PS6 và PS1.1) đều phân hủy tốt nhất hoạt chất phenol ở nghiệm thức bổ sung $\left(\mathrm{NH}_{4}\right)_{2} \mathrm{SO}_{4}$ ở tất cả các thời điểm thu mẫu.

Cụ thể, tốc độ phân hủy hoạt chất phenol của cả 3 dòng nấm men thử nghiệm trong môi trường nuôi cấy lỏng được sắp xếp theo thứ tự giảm dần như sau: $\left(\mathrm{NH}_{4}\right)_{2} \mathrm{SO}_{4}>$ casein $>\mathrm{KNO}_{3}$. Vào thời điểm sau 1 ngày nuôi cấy, nồng độ phenol còn lại trong môi trường nuôi cấy lỏng của 3 dòng nấm men ở nghiệm

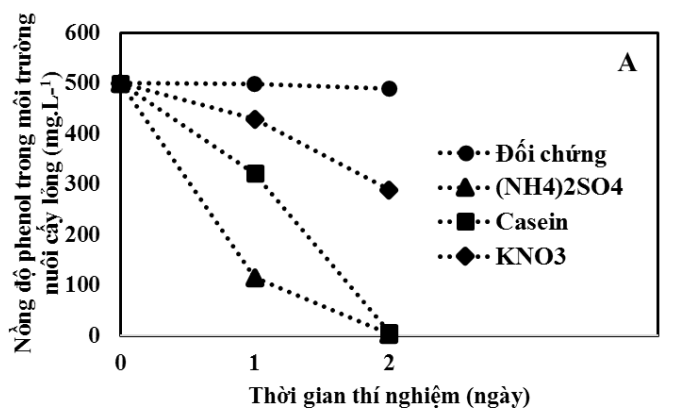

thức này lần lượt là 115,126 và $93 \mathrm{mg} . \mathrm{L}^{-1}$, trong khi đó các nghiệm thức bổ sung nguồn đạm casein và $\mathrm{KNO}_{3}$ nồng độ phenol còn lại torng môi trường nuôi cấy lỏng dao động từ 322 đến $452 \mathrm{mg} . \mathrm{L}^{-1}$. Tuy nhiên, sau 2 ngày thí nghiệm, cả hai nghiệm thức bồ sung $\left(\mathrm{NH}_{4}\right)_{2} \mathrm{SO}_{4}$ và casein kết hợp chủng riêng lẻ hai dòng nấm men ký hiệu PS1T và PS6 có lượng phenol còn lại dao động từ 0 đến $1 \mathrm{mg} \cdot \mathrm{L}^{-1}$, tương ứng với hiệu suất phân hủy hầu như $100 \%$ nguồn phenol ban đầu.

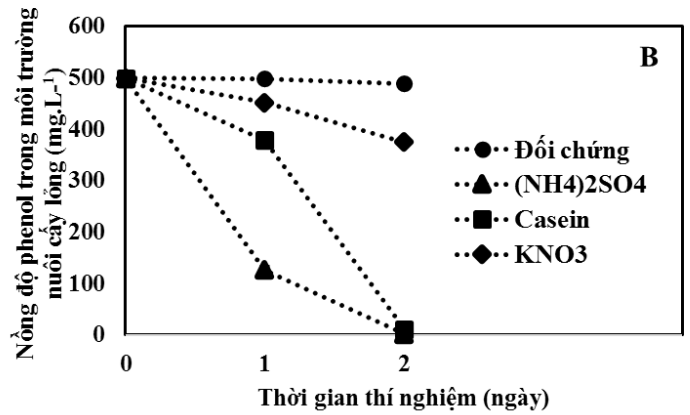

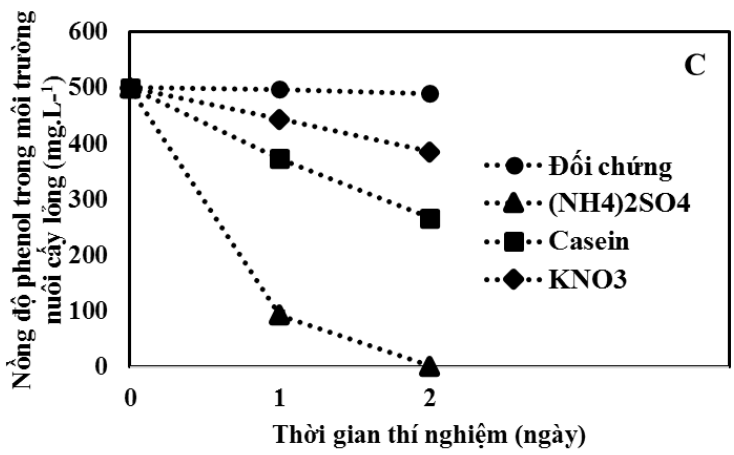

Hình 4. Khả năng phân hủy phenol của ba dòng nấm men phân lập (A: PS1T; B: PS6 và C: PS1.1) ở các nguồn đạm khác nhau trong môi trường nuôi cấy lỏng $(\mathrm{n}=3$ và độ lệch chuẩn $)$

Trong khi đó, hai nghiệm thức bổ sung đạm $\mathrm{KNO}_{3}$ kêt hợp với chủng riêng lẻ hai dòng nấm men này cho kết quả về nồng độ phenol còn lại trong môi trường nuôi cấy lỏng lần lượt là 289 và $375 \mathrm{mg} . \mathrm{L}^{-1}$, tương ứng với hiệu suất phân hủy là $42,2 \%$ và $25,3 \%$. Riêng dòng nấm men PS1.1 khả năng phân hủy phenol tiếp tục tốt nhất ở nghiệm thức bổ sung $\left(\mathrm{NH}_{4}\right)_{2} \mathrm{SO}_{4}$ với hiệu suất phân hủy đạt $100 \%$ trong khi hiệu suất phân hủy phenol của hai nghiệm thức bổ sung casein và $\mathrm{KNO}_{3}$ lần lượt là 45,3 và $22,1 \%$. Tóm lại, kết quả này cho thấy môi trường khoáng có bổ sung $\left(\mathrm{NH}_{4}\right)_{2} \mathrm{SO}_{4}$ là nguồn đạm tối ưu nhất, giúp gia tăng tốc độ phân hủy phenol của 3 dòng nấm men thử nghiệm.
3.5. Ảnh hưởng của việc bổ sung các nguồn carbon khác nhau trong môi trường nuôi cấy lỏng lên khả năng phân hủy phenol của ba dòng nấm men kí hiệu PS1T, PS6 và PS1.1

Kết quả khảo sát ảnh hưởng của việc bổ sung các nguồn carbon khác nhau trong môi trường khoáng tối thiểu lỏng lên khả năng phân hủy phenol của 3 dòng nấm men thử nghiệm (Hình 5) cho thấy khi bổ sung các nguồn carbon khác gồm $1 \%$ glucose, $1 \%$ sucrose và $1 \%$ manitol vào môi trường khoáng tối thiểu lỏng bổ sung phenol $\left(500 \mathrm{mg} . \mathrm{L}^{-1}\right)$ kết hợp chủng riêng lẻ 3 dòng nấm men thử nghiệm cho kêt quả về khả năng phân hủy phenol của 3 dòng nấm men rất kém sau 3 ngày thu mẫu so với nghiệm thức đối chứng dương (bổ sung nguồn carbon duy nhất là phenol). 

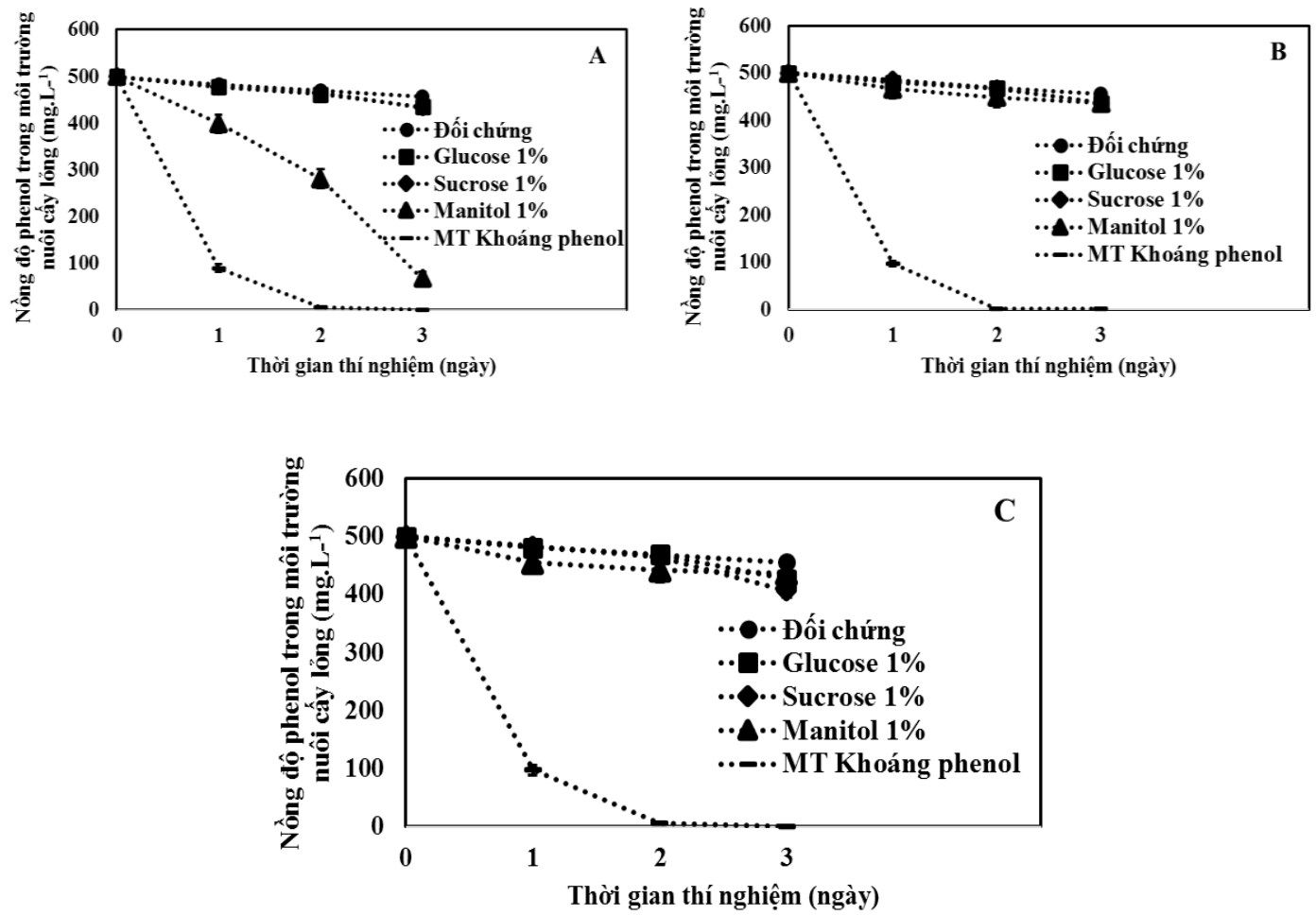

Hình 5. Khả năng phân hủy phenol của ba dòng nấm men phân lập (A: PS1T; B: PS6 và C: PS1.1) trong môi trường bổ sung nguồn carbon khác nhau ( $\mathrm{n}=3$ và độ lệch chuẩn)

Hầu hết các nghiệm thức này không khác biệt ý nghĩa thống kê $(\mathrm{p}>0,05)$ so với nghiệm thức đối chứng không chủng nấm men (dao động từ 407 đến $463 \mathrm{mg} . \mathrm{L}^{-1}$ ), ngoại trừ ở nghiệm thức chủng $1 \%$ manitol kết hợp chủng dòng nấm men PS1T. Ở nghiệm thức đó, sau 3 ngày thí nghiệm, nồng độ phenol còn lại trong môi trường là $67,5 \mathrm{mg} \cdot \mathrm{L}^{-1}$. Các nghiệm thức đối chứng dương chủng các dòng nấm men riêng lẻ kết hợp bổ sung phenol như nguồn carbon duy nhất trong môi trưởng khoáng tối thiểu lỏng (chứa $\left(\mathrm{NH}_{4}\right)_{2} \mathrm{SO}_{4} 1 \%$ ) đã phân hủy hoàn toàn phenol sau 2 ngày bố trí thí nghiệm với hiệu suất phân hủy $100 \%$. Như vậy, việc bổ sung nguồn carbon dễ phân hủy từ glucose, sucrose và manitol vào môi trường khoáng tối thiểu lỏng làm hạn chế tốc độ phân hủy phenol ở 3 dòng nấm men thử nghiệm. Điều này có thể giải thích là do khi bổ sung các nguồn carbon dễ phân hủy vào môi trường nuôi cấy, nấm men chỉ sử dụng các nguồn carbon này thay cho phenol để cung cấp năng lượng và tăng sinh khối nấm men, do đó dẫn đến giảm khả năng phân hủy phenol của vi khuẩn trong môi trường.

Tóm lại, kết quả khảo sát ảnh hưởng của các yếu tố môi trường lên khả năng phân hủy phenol của 3 dòng nấm men thử nghiệm đã cho thấy các điều kiện môi trường tối ưu nhất gồm $\mathrm{pH}$, nhiệt độ, nồng độ muối, nguồn đạm và nguồn carbon cho khả năng phân hủy phenol của 3 dòng nấm thử nghiệm được tóm tắt và trình bày ở Bảng 1 . Như vậy với $\mathrm{pH}$ môi trường nuôi cấy lỏng $=5$, ở nhiệt độ nuôi cấy $30^{\circ} \mathrm{C}$, nồng độ muối của môi trường nuôi cấy lỏng ở $0,5 \%$ và nguồn đạm từ $\left(\mathrm{NH}_{4}\right)_{2} \mathrm{SO}_{4}$ là những điều kiện môi trường nuôi cấy giúp cho 3 dòng nấm men phân hủy phenol tốt nhất trong môi trường nuôi cấy lỏng và ở điều kiện phòng thí nghiệm. 
Bảng 1. Tổng hợp hiệu suất phân hủy phenol của 3 dòng nấm men thử nghiệm tốt nhất ở các điều kiện môi trường thí nghiệm

\begin{tabular}{lrrrr}
\hline & \multicolumn{5}{c}{ Hiệu suất phân hủy phenol sau 3 ngày thí nghiệm (\%) } \\
\cline { 2 - 5 } Dòng & $\begin{array}{r}\text { pH 5 } \\
\text { Nhiệt độ 30 } \mathbf{~ C}\end{array}$ & $\begin{array}{rlr}\text { Nồng độ muối NaCl 0,5\% } \\
\text { (sau 3 ngày) }\end{array}$ & $\begin{array}{r}\left.\text { Nguồn đạm } \mathbf{( N H}_{\mathbf{4}}\right)_{2} \mathbf{S O}_{\mathbf{4}} \\
\text { (sau 2 ngày) }\end{array}$ \\
\hline PS1T & 99,72 & 99,79 & 99,85 & 99,16 \\
(sau 3 ngày) & 99,6 & 99,84 & 99,35 \\
PS1.1 & 99,69 & 99,8 & 99,82 & 99,37 \\
\hline
\end{tabular}

\section{KẾT LUẬN}

Ba dòng nấm men kí hiệu PS1T, PS6 và PS1.1 được phân lập từ mẫu bùn đáy ao ở khu xả nước thải từ các phòng thí nghiệm thuộc Khoa Nông nghiệp, Trường Đại học Cần Thơ có khả năng phân hủy hoàn toàn phenol trong môi trường khoáng tối thiểu lỏng có bố sung $500 \mathrm{mg} \cdot \mathrm{L}^{-1}$ phenol sau 3 ngày nuôi cấy. Ở các điều kiện môi trường nuôi cấy gồm $\mathrm{pH}$ 5 , nhiệt độ nuôi cấy ở $30^{\circ} \mathrm{C}$, bổ sung $\mathrm{NaCl}$ với nồng độ từ $0,5-1,5 \% \mathrm{NaCl}$ và nguồn đạm $\left(\mathrm{NH}_{4}\right)_{2} \mathrm{SO}_{4}$ là những điều kiện môi trường nuôi cấy tối ưu để 3 dòng nấm men này thể hiện khả năng phân hủy phenol tốt nhất. Ngoài ra, việc bổ sung vào trong môi trường nuôi cấy khoảng tối thiểu lỏng các nguồn carbon dễ phân hủy khác như glucose, sucrose và manitol làm ngăn cản tiến trình phân hủy hoạt chất phenol của 3 dòng nấm men thử nghiệm.

\section{TÀI LIẸU THAM KHẢO}

Moslem, A., Mehdi, H., and Arastoo, B.D. (2015). Isolation and characterization of phenol degrading bacteria from Midok copper mine at Shahrbabk provenance in Iran. Iranian Journal of Environmental Technology, 1(2), 21-34.

Bruce, R.M., Santodonato, J., \& Neal, M.W. (1987). Summary Review of the Health Effects Associated With Phenol. Toxicology and Industrial Health, 3, 535 - 568.
Filipowicz, N., Momotko, M., Boczkaj, G., Pawlikowski, T., Wanarska, M., \& Cieśliński, H. (2017). Isolation and Characterization of PhenolDegrading Psychrotolerant Yeasts. Water, Air, and Soil Pollution, 228(6), 210.

Joseph, I., \& Chandrika, V. (1999). Biodegradation of phenol using bacteria from different brackishwater habitats. Indian Journal of Marine Sciences, 28, 438-442.

Krallish, I., Gonta, S., Savenkova, L., Bergauer, P., \& Margesin, R. (2006). Phenol degradation by immobilized cold-adapted yeast strains of Cryptococcus terreus and Rhodotorula creatinivora. Extremophiles, 10, 441-449.

Lê Thị Nhi Công, Cung Thị Ngọc Mai \& Nghiêm Ngọc Minh (2013). Một số yếu tố sinh lý sinh hóa ảnh hưởng lên khả năng tạo màng sinh học chủng nấm men Trichosporon asahii QN-B1 phân hủy phenol phân lập từ Hạ Long, Quảng Ninh. Tạp chí Sinh học Viên Hàn lâm $K H \& C N$ Việt Nam, 35(3se), 106-113.

Phạm Hương Sơn, Đặng Xuyến Như \& Phạm Văn Ty (1999). Một vài đặc điểm sinh học và khả năng phân hủy hydrocarbon của hai chủng nấm men Candida tropicalis $\mathrm{HS}-10$ và HS-35. Hội nghị Công nghệ sinh học toàn quốc, 42, 170-176.

World Health Organization. (1998). Selected NonHeterocyclic Polycyclic Aromatic Hydrocacbons, Geneva, 17, 883. 